\title{
Jón Pétursson læknir og ritverk hans II
}

Örn Bjarnason, heimilislæknir og fyrrum ritstjóri Læknablaðsins

\section{Fyrri hluti pessarar greinar birtist í aprílblaðinu: Læknablaðið 2011; 97: 245-7.}

Grein pessi er að stofni til erindi sem höfundur flutti 20. febrúar 2010 i Pjóđarbókhlöđu á málpingi Félags um átjándu aldar fræða undir yfirskriftinni: Læknavísindiog heilbrigðismál á 18. og 19. öld.

\section{Lækningabókin og ritskoðun yfirvalda}

Riti Jóns Péturssonar um iktsýkina ${ }^{12}$ fylgir formáli eftir Jón Árnason, staðarhaldara á Hólum (dagsettur 23. febrúar 1782), par sem oeconomus Hoolensis getur pess, að nú hafi Jón Pétursson

utan og innan lands reyndur að lærdómi og nákvæmni við sjúka, samantekið eina lækningabók, er inniheldur útskýring á almennustu sjúkdómunum, og ræður til innlendra meðala, og peirra sem minnstum dírleika fást kunna frá apóthekinu. Pessa sína lækningabók mundi velnefndur Auctor af hendi láta til prykkingar, almenningi til nota, mundi ég og, í tilliti til sama, láta bókina prykkja, ef vissi ég hana svo útgengilega, að skaðlaus yrði, og prentverkið væri undir minni hendi framvegis.

Árið eftir sótti Jón Pétursson um að lækningabók hans yrði prentuð og í umsögn sinni til kanselísins í Kaupmannahöfn 26. september 1783 sagði Hálfdán stiftprófastur Einarsson að lækningabókin myndi koma að góðu gagni og ætti best við að hún yrði prentuð á Hólum. ${ }^{4}$ Sá var hængur á að í júní 1783 hófust Skaftáreldar og peim fylgdu hörmungarnar miklu, Móðuharðindin.

Í bréfi til rentukammersins dagsettu 23. september 1785 segist Stefán amtmaður Pórarinsson hafa beðið Jón Pétursson lækni um að pýða lækningabók sína eða láta hann hafa handritið. Með fylgja uppköst, bréf frá Jóni lækni Péturssyni til konungs og bréf frá Árna biskupi Pórarinssyni. ${ }^{15}$

Í bréfi Jóns Eiríkssonar (1728-1787) konferensráđs til Árna Pórarinssonar (1741-1787) biskups á Hólum, dagsettu 2. júní 1786, segir: „Illa var, að við eigi í fyrra haust fengum translationina af lækningabók Jóns Péturssonar. Svo hefði pað mál nú verið refererað kóngi. - Eldskrif hans eru hér undir censur ..." ${ }^{4}$ Parna var Jón Pétursson kominn í svipaða stöðu og síra Jón Steingrímsson og frændunum skyldi refsað.

Um eldskrifin (Chirurgi Jon Petersens Afhandling om Ildrögens kiendeligste Virkninger af Ildsprudningen 1783 saa vidt Norder-Island Angaaer), sem voru í ritskoðun, fjallaði Magnús Stephensen (1762-1833) í bréfi til rentukammersins í Kaupmannahöfn, dagsettu 24. Júní $1786 .{ }^{16}$

Jón Steffensen ritar athugasemd í próförk af Læknum á Íslandi (1944), sem varðveitt er í sérsafni hans í pjóðdeild Pjóðarbókhlöðu: „Jeg hef ljósrit af [bréfinu], en hef hvergi rekist á petta rit Jóns Péturssonar."

Líklega verður aldrei í ljós leitt hvað olli óvild stjórnvalda, en eitt er víst að útgáfan var stöðvuð og pegar ekki varð úr pví að Jón fengi lækningabók sína prentaða notaði hann tvo fyrstu kapítulana í grein um Orsakir til sjúkdóma á Íslandi sem hann birti í Riti Lærdómslistafélagsins árið $1891^{17}$ og árið 1794 birti hann í sama riti grein Um líkamlega viðkvæmni. ${ }^{18}$
Erla Dóris Halldórsdóttir, sagnfræðingur og hjúkrunarfræðingur, sem er að kanna starfsferil Jóns Péturssonar, hefir bent mér á gögn sem hún hefir nýlega fundið:

1. Bréf dagsett 10. júlí 1795 (endurritað af Jóni Sveinssyni landlækni). Par segir Jón Pétursson frá pví að hann geti hvorki ferðast, skrifað né lesið vegna mikillar sjóndepru. Segir hann að „poka er æði mikil á pví, aftur, svolítið get lesið gleraugnalaust af góðum stíl, litla stund, svo sem Guðspjall, pó fæ ég pá verk í pað; aldrei má ég lengi skrifa í rúmi." Segist hann jafnframt hafa ásett sér ferð suður en par sem hann „,pori hvorki né poli sterkum vindi né sandfoki að mæta auga míns vegna, jafnvel pótt nú sé pað með betra móti“ hafi hann hætt við pá ferð. ${ }^{19}$

2. Bréf dagsett 7. júlí 1795 frá Jóni Sveinssyni landlækni til Ólafs Stefánssonar stiftamtmanns, par sem hann tilkynnir honum að Jón Pétursson fjórðungslæknir í Norðlendingafjórðungi hafi óskað eftir aðstoðarlækni vegna sjóndepru sinnar og mælir með að Ari Arason verði ráðinn. Ari hafði numið læknisfræði hjá Jóni Sveinssyni frá sumri 1789 og tók próf hjá landlækni 1794. Hann var síðan aðstoðarlæknir í Nesi par til stiftamtmaður staðfesti 8. september 1795 að hann væri skipaður aðstoðarlæknir Jóns Péturssonar. ${ }^{19}$

Pá hefir Erla Dóris vakið athygli mína á pví að Ari Arason hafi verið settur læknir í Norðlendingafjórðungi 18. júlí 1801. Jón Pétursson hefir pví verið í veikindaleyfi pegar hann fór í sína síðustu vitjun eins og nú skal greint frá:

Haustið 1801 „hafði Magnús Stepensen jústizráð verið mjög vanheill; sendi hann pví norður að Viðvík til Jóns [Péturssonar]. Brá hann við skjótt og reið suður, en bað ferðamenn, er hann mætti á leiðinni, að bera kveðju ekkjunni í Viðvík. Pá er hann kom að Reykholti, var hann heill og hraustur um kveldið að pví merkt varð, en fannst örendur í rekkju sinni um morguninn eftir ... ${ }^{\text {/3 }}$ hinn 9. október 1801. „Jón hafði ritað ráð pau er hann ætlaði að hafa Magnúsi til heilsubótar og voru pau höfð undir umsjá Hallgríms Bachmanns frá Bjarnarhöfn, pví hann var pá sóktur vestur og kom að liði. “ ${ }^{3}$

Hér hefði hæglega getað orðið endir pessarar útgáfusögu, en sem betur fer tók málið heillavænlegri stefnu.

\section{Heiðruðu landsmenn}

Á pessum orðum hefst ávarp Jóns Thorsteinsen landlæknis, dagsett 26. júní 1829, sem birt var í Lækningabók fyrir almúga pegar hún kom loksins út í Kaupmannahöfn árið 1834. Landlæknir segir að Jón Pétursson hafi í bók sinni um iktsýkina 
teingt parvið kapítula, innihaldi af lækningabók peirri, sem hann hafði skrásett, frá pví hann kom hingað til lands 1772 ... Bók pessa ... endurbætti hann eptir hendinni, eins og lækningatilraunir hans gáfu honum efni til, uns hann deyði ... 1801. ... Sökum pess, að einginn gaf sig fram, er hvetti til prentunar nefndrar bókar, lá hún í dái, uns Bókprykkjari G[uðmundur] Schagfiørd og Apothekarasveinn Haldór Arnason øðludust, sá fyrri afskrift bókarinnar, en hinn aðalritið, sem afritaði pað 5 eða 6 sinnum fyrir vini sína. Árið 1828 kom pessum saman um að útgefa pessa á prent, og til til að gjøra hana sem fullkomnasta, feingu peir Landlæknir Thorsteinsen til að lesa hana ígegnum, og lagfæra hvað áfátt vera kynni, en embættis annir hans leyfðu honum ekki tóm til, að gjöra pað svo vel, sem hann vildi. Pessa vegna fengu peir Schagfjørd og Haldór Arnason, peim æfða og lærða Handlækn S[veini] Pálssyni, til allrar umbótar peirrar, er honum væri møguleg, hvað hann trúliga gert hefir, er sést af skíringargreinum hans í bók pessari ...

Boðslistar voru útsendir til allra presta í landinu, en komu fátækir tilbaka, og nokkrir aldrei. Auk pessa kom pá bilting í Prentverks stjórnina hér: Conferenceráð Stephensen frásagði sér hana framvegis, uppsagði Schagfjørd pjónusu við pað verk og veik honum á burt, en Haldór missti sjón sína og yfirgaf Apóthekið. Ímillitíð sendu peir bónarbréf sitt til Heilbrigðisráðsins í Kaupmannahöfn, leiðbeindu með vitnisburði Landlæknis um bókarinnar nytsemi fyrir almenning, um leyfi til að láta hana á prent út ganga ... ${ }^{12}$

Det Kongelige Sundheds-Collegium skrifaði landlækni 5. maí 1829 á pá leið að par sem stofnunin pekki ekki til bókarinnar verði ekki dæmt um gildi hennar. Talið sé að ekkert mæli gegn pví að bókin verði látin á prykk út ganga, par sem landlæknir hafi yfirfarið hana og komizt að raun um að hún sé við hæfi og nytsamleg og að auki sé ekkert við innsend recept að athuga. ${ }^{12}$

Næst á eftir ávarpi Thorsteinsens landlæknis er örstutt kveðja:

Par eg hefi pess nú var orðið, að síðan áðurnefnd boðsbréf útkomu, enn pótt svo fáir teiknuðu sig, sem kaupendur, á pví tímabili, hafa pó margir frétt eftir, hvørt pessi ecki mundi útkoma; margir hafa einnig í ljósi látið laungun sína til að eignast hana; svo hefi eg, ecki í ábata von, pví útgáfa bókarinnar kostar mig ærna peninga, heldur framar rækt og elsku til landa minna, keypt af Schagfjørd og H[aldóri] Arnasyni, forlagsrétt peirra til að útgefa bókina á minn eiginn kostnað, og parvið hleypt mér í verulegar skuldir. En - vonin, heiðruðu landar! gleður mig, að pér bæði hafið pau not af bók pessari, sem tilætluð eru, og ég fái líka kostnað minn endurgoldinn.

Bessastöðum pann 20. júní 1833. Porsteinn Jónsson. ${ }^{12}$

Á forsíðu Lækningabókar fyrir almúga er útgefandinn kynntur sem Porsteinn Jónsson stud. theol. og um hann segir í Íslenzkum æviskrám:

Porsteinn Jónsson Kúld (25. nóvember 1807-20. nóvember 1859). Kaupmaður og bóksali í Reykjavík. Foreldrar: Síra Jón Jónsson að Auðkúlu (biskups Teitssonar) og kona hans Jórunn Porsteinsdóttir, Jónssonar. Tekinn í Bessastaðaskóla 1826, varð stúdent 1831, með heldur góðum vitnisburði. Stundaði kennslu, var sýsluskrifari í Mýrasýslu 1837-8. Settist að í Reykjavík og kostaði bækur til prentunar ... Varð kaupmaður par 1844. Gegndi ýmsum trúnaðarstörfum í págu bæjarins ...20

Jón Steffensen hefir fjallað nánar um pau handrit lækningabókarinnar, sem enn eru varðveitt og um prentsöguna alla ${ }^{4}$ og vísast til pess.

\section{Um hvad fjallar Jón Pétursson í lækningabókinni?}

Lækningabókin er á 222 síðum og er efninu skipt í tíu kafla:

I. Um algengustu barnasjúkdóma á Íslandi (\$1-69)

II. Um kvenlega sjúkdóma (\$70-107)

III. Um almennustu sjúkdóma á körlum og konum (\$108-216)

IV. Um nokkra tilfallandi útvortis sjúkdóma (\$217-272)

V. Um blóðtökur (\$273-287)

VI Um uppsölu- og búkhreinsandi meðöl (§288-)

VII. Um klýster og stólpípur (\$298-305)

VIII. Um spansflugur, sáley, hánka og baun (\$306-312)

IX. Um hvernig sjúkdómi skal lýsa fyrir fráverandi lækni (§313-317)

X. Um læknisdóma, mæla og vigt (§318-320)

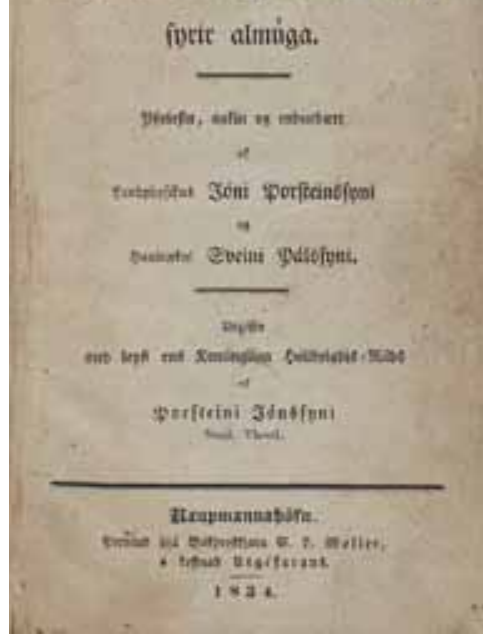

Titilsíða rits Jóns Péturssonar læknis, Lækningabók fyrir almúga, sem út kom í Kaupmannahöfn árið 1834. Ljósmynd: Helgi Bragason/ Landsbóksafn Íslands Háskólabókasafn.

Á síðu 223 hefst aðalregistur og er vísað til peirra greina par sem heitin koma fyrir. Síðan fylgir registur innlendra urta sem í bókinni eru nefndar, með peirra bótanísku nöfnum, en Jón Pétursson taldi að pessar jurtir gætu komið í stað innfluttra jurta og vildi hann með pví forða sjúklingum sínum frá ópörfum útgjöldum. Aftast er svo listi yfir bau 30 recept sem til er vísað í bókinni og eru pau hin sömu og vitnað var til í bréfi heilbrigðisráđsins í Kaupmannahöfn til landlæknis sem getið var hér að framan.

Hér ber að vekja athygli á pví að bókin fær aukið vægi vegna fjölmargra athugasemda Sveins Pálssonar neðanmáls. Lætur hann Jón Pétursson jafnan njóta sannmælis og sé Sveinn annarrar skoðunar en Jón, færir hann fram gild rök.

Jón Pétursson fjallar ekki um fæðingar eða sængurlegu, enda hafði Halldór Brynjólfsson (1692-1752) biskup á Hólum stuðlað að pví að ritið Sá nýi yfirsetu kvenna skóli eður stutt undirvísun um yfirsetu kvenna konstina ${ }^{21}$ var prentað á Hólum árið 1749 og var fyrsta kennslubókin í ljósmóðurfræði sem út kom á íslenzku. Bragi Porgrímur Ólafsson gekk frá textanum til prentunar á ný árið 2006 og í inngangi að verkinu eru greinargóðar upplýsingar um verkið, tilurð pess og viðtökur. ${ }^{22}$

\section{Í hvaða lækningarit vísuðu Jón Pétursson og Sveinn Pálsson?}

Jón Pétursson vísar í receptalistanum (No. 8) í „Herra Rósensteens Barnapillur". Par er augljóslega vitnað til sænska læknisins Nils Rosén von Rosenstein (1706-1773). Hann var kjörinn í Konunglegu sænsku vísindaakademíuna við stofnun hennar árið 1739 og par var einnig með frá byrjun læknirinn Carl von Linné (1707-1778). Árið 1740 sóttu peir báðir um prófessorsstöðu í grasafræði við Uppsalaháskóla. Heiðurinn féll Rosén í skaut, en árið eftir var Linné útnefndur prófessor í læknisfræði í Uppsölum. Árið 1742 sóttu peir um konunglegt leyfi til pess að skiptast á embættum. Var pað veitt og var samstarf peirra gott úr pví.

Sænska akademían tók sér snemma fyrir hendur að miðla vísindapekkingu til almennings í pví skyni að bæta heilsufar pjóðarinnar. Af hálfu ríkisins voru uppi áform um að draga úr ungbarnadauðanum, pví að um fjórðungur barna dó á fyrsta aldursári og um priðjungur innan fimm ára aldurs. Rosén var falið að rita greinar um barnasjúkdóma og meðferð ungbarna fyrir Sænska almanakið sem kom út í 150.000 eintökum. Kom fyrsta greinin árið 1753 og sú síðasta árið 1771.

Árið 1764 kom út bók með pví efni sem pá lá fyrir um barnasjúkdóma og varð Rosén par með fyrstur manna til pess að gefa út sér- 
staka kennslubók í peim fræðum. ${ }^{23,24}$ Bókin náði mikilli útbreiðslu og fylgdu fjórar aðrar útgáfur á sænsku til 1851, sex á pýzku (17661798), tvær á hollensku 1768 og 1779 og ein á dönsku, sem Sveinn Pálsson vitnar til í skýringargrein við §42. Í §67 segir Sveinn að hinn „nafntogaði svenski herra af Rosenstein“ hafi skrifað bók eina um barnasjúkdóma og neðanmáls segir hann: „Pessi ágæta almúgabók er á dönsku snúin af Dr. medic. P. Chr. Abildgaard, og prentuð í Kaupmannahöfn 1769". Auk pessa komu fram til 1798 út pýðingar bókarinnar í Englandi, á Frakklandi (prjár útgáfur), Ítalíu (fjórar), Austurríki (tvær) og sitt hvor á tékknesku og ungversku.

Sveinn Pálsson vitnar í pýzka lækninn Christoph Wilhelm Friedrich Hufeland (1762-1836), sem sagður var jafn frægur heima fyrir og peir Goethe, Herder og Schiller. Voru peir andans jöfrar raunar í sjúklingahópi Hufelands meðan hann var líflæknir við hirðina í Weimar. Hufeland gaf út Journal der practischen Arzney und Wundarzneykunde á árunum 1795 til 1835 og safnrit um System der praktischen Heilkunde á árunum 1818-1828. Pekktast verka Hufelands er ritgerðin Makrobiotik oder Die Kunst, das menschliche Leben zu verlängern (1797). ${ }^{25}$ Hefir hann par skilað til komandi kynslóða kenningum Hippókratesar, Aristótelesar og Galens um mikilvægi hollrar fæðu fyrir heilsuna og langlífi. Hufeland lagði pannig til heitið á næringarstefnu (macrobiotics), sem hefir öðlast nýtt líf á okkar tímum fyrir áhrif frá Austurlöndum. Рað er áðurnefnt rit Hufelands sem Sveinn Pálsson vitnar til í skýringargrein sinni við §68 í Lækningabók fyrir almúga. Ólafur Jónsson læknir hefir nýlega ritað ítarlega grein um Svein Pálsson og ævi hans og er vísað til pess. ${ }^{26}$

Hér skal látið staðar numið en pað er von mín að innan tíðar takist að endurútgefa ritið um iktsýkina, svo og og lækningabókina, með viðeigandi umfjöllun og skýringum. Jón Pétursson var slíkur andans afreksmaður, að hann á pað skilið að honum sé verðugur sómi sýndur, pó seint sé.

\section{Heimildir}

1. Blöndal LH, Jónsson V. Læknar á Íslandi. Sögufélagið, Reykjavík 1944.

2. Jónassen JP. Um læknaskipun á Îslandi. Tímarit hins íslenzka bókmenntafélags 1890; 11: 194-5, 226-8.

3. Annáll nítjándu aldar. Safnað hefur sjera Pjetur Guðmundsson frá Grímsey. Útgefandi: Hallgrímur Pjetursson, Akureyri 1912; 1: $14-5$.

4. Steffensen J. Jón læknir Pétursson og lækningabók hans. Árbók Landsbókasafns Íslands 1986; 12: 40-9.

5. Flora Danica. Det er Dansk Vrtebog. Med største Fljd oc Umage elaborerit aff Simone Paulii Anatom. Chirurg. Ac Botan. Prentet i Kiøbenhafn aff Melchiore Martzan Aar 1648. $4^{\circ} .4$ dele. 746 blade.

6. Steffensen J. Flora Danica á Íslandi. Árbók Landsbóksafns Íslands 1982; 8: 11-26.

7. Peter Wagner, sem um árabil starfaði í Botanisk Centralbibliotek í Kaupmannahöfn, hefir veitt eftirfarandi upplýsingar: Det er rigtigt, at Johann Gerhard König rejste på Island på vegne a Flora Danica og vendte hjem med en del frø, pressede planter og gouacher af tegninger. Jeg har gennemgået alle de bilag, der findes i de kongelige regnskaber (Chatol- og Partikulærkassen) og Jon Peturssons navn optræder ikke I disse bilag. Det oprindelige komplette arkiv brændte i 1884. Det kan altså ikke påvises, at han har haft noget med værket at gøre. Det betyder ikke, at han ikke har haft med det at gøre, det betyder kun, a man ikke kan påvise, at det har været tilfældet. Da bevillinger fra den kongelige kasse normalt er tildelt bestemte personer, udbetales de tilhørende kontanter til dem. De kan derefter give dem videre. Det var dog indtil 1770 normalt sådan, at udgiveren Oeder fik lov til at udbetale evt. løn eller honorar direkte. Ved hjemkomsten fra Island f. eks. medbragte König en rækk tegninger for hvilke der udbetaltes et beløb, samtidig med at værkets tegner fik en sum for at rette dem til eller tegne dem om. Jeg kan altså ikke henvise til arkivalsk dokumentation for at Jón Petursson har fået direkte løn eller honorar for at bidrage til Flora Danica.
8. Jónsson B. Íslenzkir Hafnarstúdentar. Bókaútgáfan BS, Akureyri 1949.

9. Pétursson J. Den saa kaldede Islandske Skiörbug, beskreven udi en kort afhandling af Johannes Petersen, Philosophiae Baccalaureo og Med[ecinae] Studioso. Soröe, 1769. Trykt hos Jonas Lindgren, det Ridderlige Akademies Bogtrykker.

10. Ísberg JÓ. Líf og lækningar. Íslensk heilbrigðissaga. Hið íslenska bókmenntafélag, Reykjavík 2005: 158.

11. Jóns Péturssonar Handlæknis Norðlendinga frá 1775 til 1801 Lækninga-Bók fyrir almúga. Yfirlesin, aukin og endurbætt af Landsphysikus Jóni Porsteinssyni og Handlækni Sveini Pálssyni. Utgéfin með leyfi ens Konungliga Heilbrigðis-Ráđs af Porsteini Jónssyni Stud. Theol. Kaupmannahöfn. Prentuð hjá Bókprykkjara S.L. Møller á kostnað Utgefarans 1834

12. Stutt Agrip um Icktsyke eður Lidaveike, Hvar inne hun er wtmaalud, med fleirstum sijnum Tegundum; Par eru løgd Raad, hvørsu hun verde hindrud og læknud. Samannteked af Jone Peturs Syne, Chirurgo i Nordur-lande. ... Prentad aa Hoolum i Hialtadal, Af Gudmunde Jons Syne, 1782.

13. Jónsson H. Evidence of Rheumatoid Arthritis in an Icelandic textbook from 1782. Sydsvenska Medicinhistoriska Sällskapets Årbok 1992.

14. Jónsson $\mathrm{H}$, Helgason J. Rheumatoid Arthritis in an Icelandic Textbook from 1782. Scand J Rheumatol 1996; 25: 134-7.

15. Isl. Journ. 6, nr. 470 og 793. Skjalaskrár Pjóðskjalasafns Íslands B10, $16,13,1785,1786$.

16. Pjskjs. Rtk. 42,2, 1786-1788, Islands Journal 7, fskj. nr. 104.

17. Jón Pétursson. Orsakir til sjúkdóma á Íslandi, yfirhøfud. Rit peß Íslenska Lærdóms-ListaFélags. Ellefta Bindini fyrir arit MDCCXXX. Prentat í Kaupmannahöfn 1791 á kostnað Felagsins hjá Jóhann Rúdolph Thiele, 107-169.

18. Jón Pétursson. Um líkamlega vidqæmni. Rit beß Íslenska Lærdóms-ListaFélags. Prettanda Bindini fyrir arit MDCCXCII. Utkomit í Kaupmannahöfn 1794 á kostnað Felagsins hjá Jóhann Rúdolph Thiele, 184-228.
19. jjóðskjalasafn Íslands: Skjalasafn stiftamtmanns nr. 105, III. Bréf landlæknis til stiftamtmanns 1795-1803.

20. Íslenzkar æviskrár frá landnámstímum til ársloka 1940. Tínt hefir saman Páll Eggert Ólason, Reykjavík 1952; V. bindi: 217.

21. Sá nýi yfirsetu kvenna skóli eður stutt undirvísun um yfirsetu kvenna konstina, til alminnilegrar nytsemi samanskrifaður í dönsku og forbetraður af Balthazar Johann de Buchwald ... en á íslensku útlagður af velæruverðugum og mjögvellærðum Sr. Vigfúsa Jóns Syni presti að Hítardal og prófasti í Mýra Sýslu .. prykktur á Hólum í Hjaltadal af Halldóri Eiríkssyni 1749.

22. Balthazar Johann de Buchwald. Sá nýi yfirsetukvennaskóli eður stutt undirvísun um yfirsetukvennakúnstina.Bragi Porgrímur Ólafsson bjó til prentunar og ritaði inngang. Söguspekingastifti, Hafnarfirði 2006.

23. Underrättelser om Barnsjukdomar och deras Bote-Medel. Tilförene stycketvis utgifne uti små Almanachorna, nu samlade, tilökte och förbättrade af Nils Rosén von Rosenstein, Kongl[ig] Archiater, Riddare af Nordst[järnans] Orden. Stockholm, på Kongliga Wetenskapliga Academiens kostnad, tryckte hos Direkt[ör] Lars Salvius 1764. Textinn er í heimild 21.

24. Jägervall M. Nils Rosén von Rosenstein och hans lärobok i pediatrik. Studentlitteratur, Lundi 1990.

25. Christoph Wilhelm Friedrich Hufeland. Makrobiotik oder Die Kunst, das menschliche Leben zu verlängern. Jena: Akademische Buchhandlung 1797. Dönsk pýding: Konst at forlænge det Menneskelige liv. Oversat af Werfel. Kjøbenhavn 1800 .

26. Jónsson Ó. Sveinn Pálsson, læknir og náttúrufræðingur. Fyrsti læknirinn í Vestur-Skaftafellssýslu. Dynskógar. Rit Vestur-Skaftfellinga, Vík 2009: 12; 29-49.

ENGLISH SUMMARY

\section{Dissemination of medical knowledge to the public in Iceland by a country doctor 1782-1834}

Jón Pétursson (1733-1801) was an apprentice af the first Chief Medical Officer of Iceland. In 1765 Pétursson enrolled in the Medical Faculty at the University of Copenhagen. In 1769 with the Faculties approval he published a monograph on the so called Icelandic Scurvy. In 1770-71 Pétursson served as ship's surgeon in the Royal Danish Navy on an expedition to the Mediterranean. In 1772-1775 he served as an assistant to the Chief Medical Officer and the newly appointed apothecary, who shared premises at Nes, Reykjavík. In 1775 he was appointed surgeon (chirurgeon) to the Northern District. Pétursson wrote two medical book while serving his district, both being prepared now for republication.

A. The Lækningabók fyrir almúga (Leechbook for common people) published posthumously 1834, edited by Sveinn Pálsson surgeon. It was undoubtedly inspired by the Swiss physician Tissot and his book Avis au peuple sur sa santé ou traité des maladies plus fréquentes 1761.

B. A treatise on rheumatism or dirorder of the joints (Stutt ágrip um iktsýki edur lidaveiki, 1782). In Scand J Rheumatol 1996: 25; 134-7 the authors point out that Péturssons description of what he calls arthritis vaga encompasses these essential features: It is common, chronic, destructive, inflammatory polyarthritis, sometimes with systemic manifestations. It affects peope of all ages and has a female preponderance. They state that only rheumatoid arthritis fulfills these specifications. They conclude that medical history should give Pétursson credit for the first definite description of rheumatoid arthritis. 